KS. KONRAD JÓZEF GLOMBIK

Uniwersytet Opolski

https://orcid.org/0000-0001-8461-965X

\title{
SPECYFICZNE ASPEKTY TEOLOGII W NAUCZANIU PAPIEŻA FRANCISZKA
}

Pontyfikat Franciszka zrodził wiele nadziei i oczekiwań. Wiąże się on jednak także z licznymi pytaniami i niezrozumieniem niektórych kwestii. W obszarze wielu zagadnień nauczanie papieża z Argentyny jest kontynuacją dotychczasowej nauki Kościoła, głoszonej przez jego poprzedników, zwłaszcza Benedykta XVI i Jana Pawła II. W niektórych kwestiach można wyraźnie wskazać na elementy wyróżniające nauczanie Franciszka. W związku z tym jego pontyfikat jest odbierany z wielkim entuzjazmem, ale istnieją środowiska katolickie, w tym kręgi teologów, które nie tylko krytycznie oceniają naukę głoszoną przez papieża, odbierając ją jako kontrowersyjną, ale także ją odrzucają lub uważają za szkodliwą czy heretycką ${ }^{1}$.

Specyfika pontyfikatu papieża z Argentyny nie polega jedynie na spektakularnych gestach i nowym języku, ale przejawia się również w treściach, z którymi zwraca się do wiernych. Duszpasterski charakter jego dokumentów i wystąpień łączy się z faktem, że w odróżnieniu od swojego poprzednika Franciszek nie był profesorem teologii, a na biskupa Rzymu został wybrany jako pasterz diecezji Buenos Aires. Kontekst pochodzenia, czyli związek z Ameryką Południową, w dużej mierze warunkuje treści i sposób nauczania papieża oraz rozumienie przez niego złożonych problemów współczesności. Warunkuje również proponowane przez niego rozwiązania. Duszpasterski charakter nauczania i decyzji podejmowanych przez papieża z Argentyny posiada zakorzenienie zarówno w uwarunkowaniach i doświadczeniach środowiska, z którego pochodził, w którym wzrastał i działał, ale także w rozwijanej tam teologii. Stąd inspiracji dla specyfiki nauczania Franciszka należy doszukiwać się w nurtach teologii wyzwolenia, a także w myśli i duchowości ignacjańskiej, z której się wywodzi. Z tej perspektywy trzeba interpretować i rozumieć nauczanie papieskie. Niniejszy tekst jest próbą zarysowego przedstawienia głównego przesłania płynącego z nauczania papieża Franciszka

1 Ciekawą analizę sprzeciwu wobec nauczania papieża Franciszka i podejmowanych przez niego reform zawiera artykuł: S.A. Strube, Widerstand gegen Papst Franziskus und seine Reformen. Empirische Beobachtungen am Beispiel der Internetseite kath.net, „ET-Studies” 9 (2018), n. 1, s. $27-50$. 
i jego najważniejszych inspiracji teologicznych, które ukazują optykę i specyficzne akcenty teologiczne tego pontyfikatu.

\section{TEOLOGIA LUDU W CENTRUM EKLEZJOLOGII}

Centralnym elementem specyfiki teologii w nauczaniu Franciszka jest jego wizja Kościoła, na której opiera się wiele szczegółowych zagadnień teologicznych, a także praktycznych działań i decyzji. W nauczaniu papieża w tym obszarze wyraźnie rysują się wpływy argentyńskiego teologa Lucio Gera (1924-2012), który razem z Gustavo Gutérriezem uczestniczył w konferencji zwołanej przez radę biskupów latynoamerykańskich w Pertropolis w 1964 r., a która uchodzi za narodziny teologii wyzwolenia. To wówczas Gera wygłosił referat na temat znaczenia przesłania chrześcijańskiego w kontekście nędzy i ucisku. Tematyka ta stała się głównym rysem wszystkich form teologii wyzwolenia i opiera się na metodzie „widzieć-oceniać-działać”. Gera nadał argentyńskiej teologii wyzwolenia specyficzny profil. Punktem wyjścia nie jest dla niego analiza warunków społeczno-politycznych i ekonomicznych oraz napięć i przeciwieństw w społeczeństwie oraz ich interpretacja w sensie teorii marksistowskich, ale historyczna analiza kultury ludu, który jednoczy się wokół wspólnego etosu. Chodzi o teologię ludu i kultury, która nie zamierza go pouczać, ale słucha jego mądrości, a przy tym duże znaczenie przypisuje formom pobożności ludowej. Teologia ta uwzględnia istniejące napięcia społeczne, ale w ich rozwiązywaniu nie kieruje się ideą walki klas, lecz myślą o harmonii, pokoju i pojednaniu².

Zakorzenienie swojego nauczania o Kościele w teologii ludu Franciszek jednoznacznie potwierdził w wywiadzie przeprowadzonym przez Dominique'a Woltona, w którym stwierdził: „W przypadku teologii wyzwolenia później zmieniono jej nazwę i nazwano «teologią ludu». Niezbyt lubię to określenie, ale pod taką nazwą ją poznałem. Iść z ludem Bożym i uprawiać teologię kultury. [...] słowo «lud» nie jest słowem logicznym. Jest to słowo mityczne. Nie sposób mówić o ludzie logicznie, gdyż byłby to jedynie opis. By zrozumieć jakiś lud, by pojąć jego wartości, trzeba wniknąć w jego ducha, w jego serce, w pracę, w historię i w mit jego tradycji. Ta teza jest naprawdę istotna dla zrozumienia teologii zwanej «teologią ludu». To znaczy iść z ludem, patrzeć, poprzez co się wyraża”’3. Franciszek jest przekonany,

2 W. Kasper, Papst Franziskus - Revolution der Zärtlichkeit und der Liebe. Theologische Wurzeln und pastorale Perspektiven, Stuttgart: Katholisches Bibelwerk 2015, s. 26-27; C.M. Galli, Ein Lateinamerikaner in Rom. Franziskus und die argentinische Theologie des Gottesvolkes, Herder Korrespondenz Spezial (2015), n. 1, s. 16-17.

3 Franciszek, D. Wolton, Otwieranie drzwi. Rozmowy o Kościele i świecie, thum. M. Chojnacki, Kraków: WAM 2017, s. 48. 
że „Kościół powinien wejść w lud, powinien być z ludem, pomagać mu wzrastać, wspomagać rozwój jego kultury. Lud powinien sprawować liturgię w określony sposób... To właśnie wielki wkład Soboru Watykańskiego II: inkulturacja"4.

Teologia ludu, która zrodziła się w Argentynie, nie jest konserwatywną alternatywą dla teologii wyzwolenia, ale teologią wyzwolenia bez marksizmu. Zwłaszcza Gutérriez podkreślał, że stanowi ona uprawnioną formę teologii wyzwolenia, której istotnym elementem jest pobożność ludowa wyzwolona z „,dewocjonalizmu” i „oświeceniowych” uprzedzeń, co podnosi ją do rangi miejsca teologicznego i dowodu inkulturacji wiary w specyficznej formie latynoamerykańskiej. W przekonaniu Franciszka teologia ludu dystansuje się zarówno wobec ideologii populistycznych, jak i systemu marksistowskiego obstającego przy abstrakcyjnych kategoriach burżuazji i proletariatu. W jej centrum znajduje się wierny lud, który staje się symbolem historycznego sposobu, w jaki wiara „unerwia” życie, wpływając na rzeczywistość i kulturę, a jednocześnie wyraża sposób, w jaki dokonuje się Wcielenie. Nie chodzi przy tym o socjologię akademicką, ale o historyczną podstawę, na bazie której toczy się życie, a która karmi wiarę Kościoła. Chrześcijańska wiara ludu jest miejscem teologicznym, miejscem wiary „inkulturowanej”, czyli przeżywanej w konkretny sposób ${ }^{5}$.

Rozumienie Kościoła jako ludu Bożego znajdujące się w centrum nauczania Franciszka jest mocno zakorzenione w tradycji biblijnej, patrystycznej i liturgicznej i zostało na nowo podjęte przez Sobór Watykański II. Przedstawił on Kościół jako mesjański lud Boży (KK 9-12). O ile w teologii europejskiej taka wizja nie spotkała się z głębszą recepcją z racji podejrzenia o zbyt mocny charakter socjologiczny, polityczny i odnoszący się do ekonomii, ujęcie soborowe zainspirowało latynoamerykańskich teologów i znalazło wyraz w teologii ludu, którą Franciszek wypełnia konkretnymi treściami. Z tej perspektywy można rozumieć styl jego papieskiej posługi, która nie jest ani dobroduszną ludowością, ani tanim populizmem, ale wyrazem bliskości duszpasterskiej z ludem, za czym stoi teologia, a nawet jego mistyka. Według Franciszka Kościół jest czymś więcej niż organiczną i hierarchicznie uporządkowaną instytucją. Papież rozumie go przede wszystkim jako lud Boży w drodze do Boga, lud pielgrzymujący i ewangelizujący, który przekracza niezbędny wymiar instytucjonalny. Ostatecznie Kościół jest zakorzeniony w tajemnicy Trójcy Przenajświętszej, a zbawienie staje się dziełem Bożego miłosierdzia. Jedynie dzięki swojej łasce Bóg mocą Ducha Świętego pociąga nas ku sobie nie jako jednostki, ale jako swój lud i tworzy z nas właśnie taką wspólnotę. W tak rozumianym Kościele prymat wiedzie łaska, dzięki której jest on miejscem niezasłużonego miłosierdzia, w którym wszyscy mogą czuć

4 Franciszek, D. Wolton, Otwieranie drzwi, s. 50.

5 M. Borghesi, Jorge Mario Bergoglio. Biografia intelektualna. Dialektyka i mistyka, tłum. D. Chodyniecki, Kraków: Bratni Zew 2018, s. 105-112. 
się zaakceptowani, kochani, doświadczają przebaczenia i umocnienia, aby żyć zgodnie z Ewangelią ${ }^{6}$.

Kościołowi jako ludowi Bożemu została powierzona misja ewangelizacji świata, która aktualnie polega na „misyjnym wyjściu” i „docieraniu na peryferie egzystencjalne", jak zostało to określone w programowej dla pontyfikatu Franciszka adhortacji apostolskiej Evangelii gaudium. Według papieża zadanie to obejmuje wszystkich wierzących i nie jest jedynie domeną wykwalifikowanych osób. Opiera się ono na przekonaniu, że we wszystkich ochrzczonych działa uświęcająca moc Ducha Świętego, która pobudza do ewangelizowania wszystkich współwyznawców w Chrystusie. Namaszczenie Duchem Świętym sprawia, że lud Boży jest nieomylny in credendo, co znaczy, że wierząc, nie błądzi. Ponadto Bóg obdarza ogół wiernych sensus fidei, czyli zmysłem wiary, który pomaga rozeznawać to, co pochodzi od Najwyższego. W konsekwencji każdy członek ludu Bożego - niezależnie od pełnionej funkcji w Kościele i stopnia wykształcenia w wierze - jest aktywnym podmiotem ewangelizacji. Osoba wierząca, która doświadczyła miłości Stwórcy, staje się misjonarzem w takiej mierze, w jakiej spotkała się z miłością Boga w Chrystusie Jezusie. W tym kontekście nieuzasadniony okazuje się podział na uczniów i misjonarzy, gdyż wszyscy w Kościele są uczniami misjonarzami ${ }^{7}$. Dotyczy to także posługi biskupa, który ,[...] niekiedy stanie z przodu, aby wskazać drogę i podtrzymać nadzieję ludu, innym razem zwyczajnie stanie pośród wszystkich ze swą prostotą i miłosierną bliskością, a w pewnych okolicznościach powinien iść za ludem, aby pomóc tym, którzy zostali z tyłu, a przede wszystkim dlatego, że sama owczarnia ma swój węch, aby rozpoznać nowe drogi"s.

Słusznie zauważył Paolo Renner, że w kwestii wizji Kościoła Franciszek nie proponuje polityki małych kroków, ale prawdziwą rewolucję eklezjalną i eklezjologiczną, której profilem jest transformacja misyjna Kościoła. Papież pragnie Kościoła otwartego, wychodzącego naprzeciw świata i proponuje jego model generatywny, a nie konserwatywny. Nie chodzi o mater et magistra, ale o matkę, która potrafi słuchać i uczyć się od innych, żyjąc bliskością będącą stylem życia ewangelizatorów i wszystkich wierzących. Kościół ma być matką troskliwą i otwartą, która nie lęka się utraty własnego życia, by ofiarować je innym. Dodatkowo, jak każda

6 W. Kasper, Papst Franziskus - Revolution der Zärtlichkeit und der Liebe, s. 53-55. Więcej na temat recepcji soborowej wizji Kościoła jako ludu Bożego zob.: S. Noceti, Volk Gottes: Eine noch nicht vollendete Wiederfindung des Selbstverständnisses der Kirche, Concilium (D) 54 (2018), z. 3, s. 240-252; R. Luciani, Der zentrale Stellenwert des Volkes in der Soziokulturellen Theologie von Papst Franziskus, Concilium (D) 54 (2018), z. 3, s. 297-308; G. Comeau, La dynamique spirituelle de L'Église dans le monde, selon le pape François. Point de vue d'une théologienne françasie, „ET-Studies" 9 (2018), n. 1, s. 51-60.

7 Franciszek, Adhortacja apostolska ,Evangelii gaudium”, Watykan 2013 (dalej: EG), nr 120; R. Luciani, Der zentrale Stellenwert des Volkes in der Soziokulturellen Theologie von Papst Franziskus, s. 301-304.

8 EG 31 . 
matka powinien kroczyć z własnymi dziećmi - wiernymi - po drogach czasu. Kościół musi zatem być otwarty, a nie koncentrować się na samym sobie. Ważne, by skupiał się zwłaszcza na Ewangelii, służbie i autorytecie, którego zasady wzrostu nie stanowi wszystko korumpująca władza. Jako lud w drodze może i powinien być przestrzenią przyjęcia, domem otwartym, w którym znajdzie się miejsce dla każdego z jego trudnym życiem, a pozycję uprzywilejowaną zajmują ubodzy9.

Przesunięcie akcentu $\mathrm{z}$ wymiaru eklezjalno-hierarchicznego w kierunku wizji Kościoła jako ludu Bożego zostało wyraźnie zaznaczone w adhortacji apostolskiej Amoris laetita. W dokumencie tym pobrzmiewa echo narastającej od kilku dziesięcioleci krytyki tendencji teologicznej, która polega na przypisywaniu większego znaczenia jednolitości i wierności tradycji kościelnego nauczania niż kształtowaniu chrześcijańskich postaw odpowiadających sytuacji, a także podkreśla istotniejszą rolę posłuszeństwa regułom wyznaczanym przez Urząd Nauczycielski Kościoła niż formacji sumienia wiernych. Idea Kościoła jako ludu Bożego obejmuje wszystkich ochrzczonych, którzy są w drodze do Boga przebiegającej przez czas i historię. Istotnym elementem rozumienia Kościoła jako ludu Bożego jest synodalność, która zajmuje miejsce centralizmu i polega na wspólnym podążaniu wszystkich ochrzczonych, wiernych świeckich i duchownych do Stwórcy oraz wsłuchiwaniu się w Jego głos i w to, co jest tu i teraz Jego wolą, którą rozpoznajemy w zmyśle wiary i charyzmatach wierzących ${ }^{10}$. Centralnym elementem eklezjologii Franciszka, definiującym stałe nawrócenie pastoralne jako oś nadającą strukturę papieskiej teologii społeczno-kulturowej, stanowi uznanie, że wezwanie Boże objawia się w duszy ludów, ich sumieniu i hermeneutyce. Jest to szczególny element recepcji Soboru Watykańskiego II, który dał impuls dla Kościoła w drodze, istniejący w ludzie i w nim znajdujący urzeczywistnienie swojej istoty i posłannictwa ${ }^{11}$.

Tak zarysowanej eklezjologii w nauczaniu Franciszka towarzyszy krytyka klerykalizmu, który jest zaprzeczeniem rozumienia Kościoła jako ludu Bożego, powodem wynaturzeń w pełnieniu w nim władzy oraz zachowań sprzecznych

9 P. Renner, L'ecclesiologia fondata nella biografia di Papa Francesco, „Brixner Theologisches Jahrbuch/Annuario Teologico Bressanone" (2015), s. 160-163. Więcej na temat rozumienia i oczekiwań wobec eklezjologii ludu według Franciszka zob.: Ch. Weisner, Wendezeit für die römische Kirche. Der schwierige Weg von der Klerikalkirche zu einer Kirche des Gottesvolkes, „ET-Studies” 9 (2018), n. 1, s. 3-26; J.A. Gomes Moreira, Fünf Jahre Franziskus - aus der Perspektive der Befreiungstheologie, „ET-Studies”9 (2018), n. 1, s. 61-88.

10 H.J. Pottmeyer, Volk Gottes auf dem Weg. Das Kirchenverständnis von Papst Franzskus als Schlüssel zu Amoris laetitia, w: S. Goertz, C. Wittig (ed.), Amoris laetitia - Wendepunkt für die Moraltheologie?, Freiburg im Br.: Herder 2016, s. 326-328; J.C. Scanonne jako trzy istotne elementy teologii ludu według Franciszka podaje: zmysł wiary, pobożność ludową oraz preferencyjną opcję na rzecz ubogich. Więcej na temat teologii ludu w rozumieniu Jorge Bergoglio i jej zakorzenieniu w nurtach teologii wyzwolenia w Ameryce Łacińskiej zob. J.C. Scannone, Pope Francis and the Theology of the People, „Theological Studies” (2016), no 1, s. 118-135; C.M. Galli, Ein Lateinamerikaner in Rom, s. 16-19.

11 R. Luciani, Der zentrale Stellenwert des Volkes in der Soziokulturellen Theologie von Papst Franziskus, s. 306. 
z przesłaniem Ewangelii ${ }^{12}$.W przekonaniu papieża z Argentyny klerykalizm stanowi jedną z poważniejszych przyczyn kryzysu w Kościele, związanego ze skandalami pedofilskimi wśród duchowieństwa. Jest to postawa, która unicestwia osobowość chrześcijanina i prowadzi do umniejszania i niedoceniania łaski chrzcielnej, którą Duch Święty złożył w serach wierzących. Przejawia się w zachowaniach osób zarówno duchownych, jak i świeckich, powoduje rozłam w Kościele i sprzyja rozwojowi różnych form zła, w tym pedofilii. Klerykalizm to tożsamość bez przynależności do ludu i zaprzeczenie prawdy, że Bóg zbawił ludzi i wchodzi w ich dynamikę; to postawa zastępowania, wyciszania, pomijania, ograniczania ludu Bożego do małych elit; tworzenia wspólnoty, planów, podejść teologicznych, duchowości i struktur bez korzeni, bez pamięci i bez życia ${ }^{13}$.

W przekonaniu Thomasa Schärtla klerykalizm, będący jedną z przyczyn skandali pedofilskich w Kościele, stanowi aktualnie poważne wyzwanie dla eklezjologii i przemyślenia trzech istotnych kwestii. Pierwsza z nich dotyczy relacji Kościoła lokalnego do Kościoła powszechnego, Kościołów lokalnych wobec siebie, a także posługi Piotra w służbie jedności Kościoła oraz przyszłości Kościołów lokalnych, którym brakuje siły i wiarygodności w czasie kryzysu. Druga kwestia obejmuje większe zaangażowanie wiernych świeckich w przezwyciężenie aktualnych problemów pojawiających się w Kościele, a także zintensyfikowanie ich udziału i poczucia współodpowiedzialności w gremiach decyzyjnych oraz kontrolnych Kościoła. Trzecia kwestia jest najbardziej delikatna - łączy się bowiem z rozumieniem sakramentu święceń, co dotąd w dużej mierze opierało się na teologii zabarwionej jansenistycznie, o charakterze etyczno-elitarnym i mistycznym, negującej ,ja" osoby przyjmującej święcenia, by móc działać in Persona Christi. Takie podejście prowadziło do kultywowania świadomości kapłańskich elit i ich wyjątkowości. Kryzys urzędu w Kościele może zostać przezwyciężony jedynie na drodze teologii i duchowości urzędu, które poważniej traktują inkarnacyjno-sakramentalny wymiar chrześcijaństwa. Dzięki temu osoba przyjmująca święcenia w swoim zadaniu reprezentowania Chrystusa i przewodzenia wspólnocie jest narzędziem zbawienia, którego skuteczność i wiarygodność istotnie wiąże się z jej biografią. Przyjmującemu święcenia nie gwarantuje autentyczności prowadzące do dysocjacji wyrzeczenie się siebie, lecz oparta na pojednaniu z samym sobą akceptacja swojej osoby, w której własne niedoskonałości i ograniczenia nie zostają wyparte czy upiększone, ale wprzęgnięte w realizację życiowego powołania ${ }^{14}$.

12 Franciszek, Rachunek sumienia. Przemówienie do czlonków Kurii Rzymskiej (22.12.2014), „L'Osservatore Romano” (Pl) 36 (2015), nr 1, s. 39-42.

13 Franciszek, Niech Duch Święty da nam łaskę nawrócenia i zadośćuczynienia. List do Ludu Bożego, „L'Osservatore Romano” (Pl) 39 (2018), nr 8-9, s. 8.

14 T. Schärtl, Amerikanischer Albtraum. Die perfide Interpretation des Missbrauchs, ,Stimmen der Zeit" (2018), n. 11, s. 764-766. 


\section{ZAKORZENIENIE W DUCHOWOŚCI IGNACJAŃSKIEJ}

Kolejną specyficzną cechę nauczania Franciszka stanowi teologia kerygmatyczna, która przeniknięta jest myślą św. Ignacego z Loyoli. Za punkt wyjścia w tej teologii nie uznaje się - w duchu założyciela jezuitów - nauki, ale konkretną sytuację. Nie chodzi przy tym o zwyczajne dopasowanie się do niej, ale o jej ocenę zgodnie z zasadą rozeznawania duchów, co przewidują ćwiczenia duchowe św. Ignacego. Za pomocą rozeznawania duchowego dochodzi się do konkretnych praktycznych decyzji. W rozumieniu Świętego w tej praktyce, o której mowa już w Nowym Testamencie (Rz 12,2; 1Kor 12,10; 1Tes 5,21; 1J 4,1), chodzi o odpowiedź na pytanie o to, czego Bóg oczekuje ode mnie w konkretnej sytuacji. W tym sensie pisał Karl Rahner, podejmując temat poznania egzystencjalnego, czyli poznania konkretnej woli Bożej skierowanej do każdego poszczególnego człowieka. Ważne okazuje się zatem osobiste rozeznanie. Sobór Watykański II w nawiązaniu do nauczania papieża Jana XXIII zastosował tę metodę w konstytucji duszpasterskiej o Kościele w świecie współczesnym Gaudium et spes, w której mówi się o znakach czasu i wyjaśnianiu ich w świetle Ewangelii. Oparte na rozeznawaniu podejście Franciszka nie dotyczy treści prawd teologicznych, ale metody teologicznej posiadającej charakter bardziej kerygmatyczny, a mniej pouczający. W konsekwencji należy postrzegać nauczanie papieża z punktu widzenia hermeneutyki kontynuacji w zakresie pryncypiów, przy jednoczesnej dyskontynuacji w obszarze ich praktycznego zastosowania ${ }^{15}$.

Specyficzna hermeneutyka jest szczególnie wyraźna w podejściu Franciszka do rozumienia sakramentu małżeństwa. W tym obszarze papież podtrzymuje ciągłość nauczania i wiary Kościoła, a jednocześnie proponuje hermeneutykę odczytywania życia z poszanowaniem jego zawiłości i uwzględnianiem meandrów oraz ślepych uliczek. Takie podejście prowadzi do odzyskania konkretnego i realnego znaczenia sakramentu małżeństwa wyrażającego podążanie za działaniem łaski, którą Bóg składa w związku małżeńskim. W ten sposób papież z Argentyny wytycza nowe szlaki dla refleksji teologicznej i praktyki duszpasterskiej Kościoła ${ }^{16}$, które powinny być ze sobą zespolone. Szczególnie wymownie brzmią w tym kontekście wypowiedziane przez niego słowa: „Doktryna teologiczna, która nie pozwala się ukierunkować i ukształtować przez cel ewangelizacyjny i przez troskę duszpasterską Kościoła, jest tak samo nie do pomyślenia jak duszpasterstwo, które nie potrafiłoby docenić Objawienia i jego tradycji w perspektywie lepszego zrozumienia

15 W. Kasper, Papst Franziskus - Revolution der Zärtlichkeit und der Liebe, s. 18-21.

16 G. Barth, Amoris laetitia - ciagłość czy zerwanie? Kwestie hermeneutyczne, w: J. Goleń (red.), Towarzyszyć malżeństwu i rodzinie. Inspiracje adhortacji apostolskiej Amoris laetitia dla duszpasterstwa rodzin, Lublin: TN KUL 2017, s. 48-49. 
i przekazywania wiary"17. W istocie chodzi o fronetyczny model uprawiania refleksji, odpowiadający współczesnym standardom nauk humanistycznych, których potencjał intelektualny powinien mieć rezonans w codzienności. Dla Franciszka ważne jest wzajemne przenikanie się teorii i praktyki. Duszpasterstwo, które bazuje na refleksji teologicznej, odcina się od małoduszności i ciasnoty, stanowiąc wyraz zaufania bardziej człowiekowi i jego możliwościom niż kanonom, normom, wytycznym i instrukcjom. Nie oznacza to kwestionowania ich znaczenia, a jedynie zmianę podejścia do tej sfery ${ }^{18}$.

Franciszek w swoim nauczaniu sprowadza to, co instytucjonalne w Kościele, na dalszy plan, a w centrum stawia doświadczenie Boga i niewypowiedziane tajemnice. W konsekwencji Bóg nie jest obecny jedynie w ścisłej kalkulacji porządku kościelnego i w ten sposób nie stanowi przeciwieństwa rzekomego złego świata. W przekonaniu papieża istotą egzystencji jezuickiej jest przywoływanie łask Bożych przeszłości, dzielenie ich z Bogiem w przyjaznej rozmowie, dzięki czemu powstaje zażyłość z Nim, co z kolei umożliwia zaangażowanie na rzecz królestwa Bożego. Do przekonania o osobistej relacji wierzącego z Bogiem, będącej podstawą ewangelizacji, dochodzi druga ważna zasada ignacjańska, mówiąca o tym, że Stwórcę można odnaleźć we wszystkich rzeczach. Przeświadczenie o obecności śladów Boga w świecie, także wśród jego brudu, prowadzi do trzeciej zasady, będącej centralnym elementem duchowości ignacjańskiej, czyli do rozeznawania duchów. Chodzi o sprawdzenie tego, czy określona myśl, zamiar działania albo plan rzeczywiście pochodzą od Boga, od dobrego Ducha, czy też są niezgodne z Jego wolą, a zatem wywodzą się od złego ducha. Rozeznawanie nie jest sprawą banalną i łatwą, gdyż zły duch postępuje w sposób wyrafinowany i pod pozorem dobra podaje wskazówki, które człowieka zwodzą ku drodze grzechu. W związku z tym rozeznawanie duchów domaga się dodatkowo wyczucia i doświadczenia. Jeśli jest się w tej sztuce obeznanym, to umożliwia ona rozpoznawanie woli Bożej w konkretnej sytuacji także wtedy, kiedy nie odpowiada ona w pełni społecznym, kościelnym i osobistym oczekiwaniom albo pozostaje z nimi sprzeczna ${ }^{19}$.

Także dodatkowe reguły ważne w tej sztuce są zakorzenione w duchowości ignacjańskiej i zostały przedstawione przez Franciszka w adhortacji apostolskiej Evangelii gaudium jako zasady kierujące rozwojem życia społecznego i budowania ludu, w którym różnice stanowią harmonijną całość w obrębie jednego projektu. Zastosowanie tych zasad może stanowić drogę do pokoju ${ }^{20}$. Sformułowania tych

17 Franciszek, Piękno chrześcijańskiej rodziny. Przemówienie do członków Papieskiego Instytutu Studiów nad Matżeństwem i Rodzina im. Jana Pawła II (27 X 2016), „L'Osservatore Romano” (Pl) 37 (2016), nr 11, s. 35.

18 G. Barth, Amoris laetitia - ciagłość czy zerwanie? Kwestie hermeneutyczne, s. 49-50.

19 N. Wandinger, Aus persönlicher Gotteserfahrung unterscheiden, entscheiden und (dramatische) Prozesse anstossen. Zur ignatianischen Spiritualität von Past Franziskus, „Brixner Theologisches Jahrbuch/Annuario Teologico Bressanone" (2015), s. 202-205.

20 EG 221. 
zasad dokonał Jorge Bergoglio, wówczas prowincjał Towarzystwa Jezusowego, kiedy w konkretnym kontekście społecznym doświadczał konfliktów polityczno-społecznych i ideologii, które miały tendencję do wznoszenia nieprzekraczalnych murów, wywoływania nienawiści i prowadziły do licznych ofiar. Jako jezuita zabiegał wtedy o jedność Kościoła i jedność ludu, postulując zasadę zbieżności przeciwieństw (coincidentia oppositorum), zgodnie z którą w ich syntezie znajduje się idealny cel. Pierwsza z tych zasad - ,jedność jest ważniejsza niż konflikt” - ma na względzie ukazać inny punkt widzenia, który bez cenzurowania napięć i problemów nie prowadzi jednak do rozbicia jedności ludu. Jedność nie może być narzucona ani pozbawiona konfliktu, stanowi bowiem rezultat napięcia, które w niektórych sytuacjach znajduje rozwiązanie w syntezie wykraczającej poza antagonizm przeciwstawnych biegunów i dążącej do pojednania różnorodności. Druga zasada - „całość jest ważniejsza od części” - ma na celu wyjście z polaryzacji, które dla chrześcijanina polega na przyjęciu Boga jako semper maius, i zaakceptowaniu planu Bożego większego od ludzkich projektów. Nie chodzi przy tym o usuwanie kontrastów, ale o niedopuszczenie do ich absolutyzowania. Kolejna zasada - „czas jest ważniejszy niż przestrzeń” - ukazuje metodę dochodzenia do syntezy. W odróżnieniu od woli panowania, która dąży do zajmowania miejsc i okupowania przestrzeni, przypisuje duże znaczenie procesom. Ostatnia zasada - „rzeczywistość jest ważniejsza od idei” - postuluje powrót do kategorii możliwości w przeciwieństwie do fascynacji ideologią rewolucyjną i roszczeniami, by świat zmieniać w oparciu o elitarne awangardy. Bergoglio określił powyższe zasady ignacjańską koncepcją zharmonizowania przeciwieństw, która bazuje na idei spotkania, dialogu i łączności. Pobrzmiewa w niej siedemnastowieczny spór między moralną refleksją jezuitów, zwracających uwagę na konkret, a sztywną i odczłowieczoną myślą moralną jansenizmu. W istocie chodzi o jedność, która nie eliminuje różnorodności i nie tłumi konfliktu. Chodzi zatem o jedność w napięciu, uznającą wartość biegunowości, uniemożliwiając tym samym jej rozmycie w sprzeczności. Jedność nieusuwająca różnorodności jest koncepcją dialektyczną, która w odróżnieniu od dialektyki heglowskiej nie urzeczywistnia się w syntezie dokonywanej przez rozum, ale przez wyższą zasadę, czyli Deus semper maior. Synteza ta stanowi rezultat spotkania łaski z naturą, Boga z człowiekiem, inności z wolnością ${ }^{21}$. Zasady przywołane przez Franciszka mogą znaleźć zastosowanie w przewodzeniu Kościołowi² , ale są także dobrą propozycją formuły przywództwa dla innych społeczności, w których istotne znaczenie ma kierowanie się odpowiedzialnością i troską o dobro wspólne ${ }^{23}$.

${ }^{21}$ M. Borghesi, Jorge Mario Bergoglio. Biografia intelektualna, s. 117-133; zob. także: M. Tomasi, Quattro principi per dare forma ad un popolo. Il contributo dell'esortazione apostolica Evangelii gaudium alla dottrina sociale Della Chiesa, „Brixner Theologisches Jahrbuch/Annuario Teologico Bressanone" (2015), s. 169-185.

22 J.C. Scannone, Pope Francis and the Theology of the People, s. 131.

23 E. Gillen, Leadership in eine offene Zukunft! Die Papst-Franziskus Formel, „Studia Teologiczno-Historyczne Śląska Opolskiego" 36 (2016), n. 2, s. 11-30; E. Gillen, Menschliche 
Zawarta w powyższych zasadach konstruktywna droga rozwiązywania konfliktów bazuje na ignacjańskim przekonaniu o tym, że Duch Święty jest źródłem różnorodności między ludźmi. Nawet jeśli różnice wydają się obciążeniem to dzięki Duchowi Świętemu, odpowiednio kierującemu ludzkimi sercami, nabierają one wymiaru ubogacającego. Święty Ignacy był przekonany nie tylko o tym, że Duch Święty jest sprawcą różnorodności między ludźmi i ludzkimi społecznościami, lecz także o tym, że w tej samej kwestii może różnych ludzi prowadzić do odmiennych przekonań. Nie chodzi przy tym o to, że zaprzecza samemu sobie, ale potwierdza, że w ramach rozeznania duchowego i osobistego doświadczenia Boga człowiek może ujmować wolę Bożą jedynie z własnej zawężonej perspektywy ${ }^{24}$.

Charakterystyczne dla duchowości ignacjańskiej, a także dla nauczania papieża Franciszka, staje się to, że rozeznawanie prowadzi do podjęcia decyzji. Nie chodzi o proste quasi-obiektywno-neutralne stwierdzenie, że Bóg jest tu obecny i działa. Ważniejsze staje się to, że rozeznanie duchowe podsuwa człowiekowi decyzję ukierunkowaną na wybór. Może obejmować zarówno dylematy życiowe związane z wyborem powołania, jak też codzienne rozterki związane chociażby z wyborem środka lokomocji. Dla podjęcia dobrej decyzji św. Ignacy z Loyoli podał kryteria, wśród których największe znaczenie przypisywał jasności i zrozumieniu na podstawie doświadczenia w pocieszeniu i beznadziei oraz w rozróżnianiu różnych duchów. Pocieszenie i beznadzieję postrzegał jako uwarunkowane sytuacyjnie i osobowo dla rozeznawania duchowego. W przypadku osoby zaawansowanej na drodze nawrócenia i dojrzewania duchowego doświadczenie pocieszenia jest znakiem tego, że działa w niej dobry duch. Ten znak można dostrzec szczególnie wtedy, kiedy pocieszenie następuje bez wcześniejszej przyczyny ${ }^{25}$.

\section{MIŁOSIERDZIE KLUCZOWYM POJĘCIEM TEOLOGICZNYM}

Kluczowym pojęciem teologicznym niezbędnym do interpretacji i zrozumienia nauczania papieża Franciszka jest miłosierdzie. Miserando atque eligendo było zawołaniem biskupim Jorge Bergoglio, a miłosierdzie obecne w jego nauczaniu jako papieża od początku pontyfikatu stanowi motyw przewodni jego działalności. Pojęcie to jest centralnym przesłaniem biblijnym, obecnym zarówno w Starym Testamencie, jak i w nauczaniu Jezusa, gdzie widać je znacznie wyraźniej. Święty

Sicherheit ethisch aufladen und politisch nutzbar machen, Concilium (D) 54 (2018), z. 2, s. $136-143$.

${ }^{24}$ N. Wandinger, Aus persönlicher Gotteserfahrung unterscheiden, entscheiden und (dramatische) Prozesse anstossen, s. 211-212.

25 N. Wandinger, Aus persönlicher Gotteserfahrung unterscheiden, entscheiden und (dramatische) Prozesse anstossen, s. 208-209. 
Tomasz z Akwinu w nawiązaniu do myśli św. Anzelma z Canterbury ukazał miłosierdzie jako wyrażaną na zewnątrz istotę Boga, jako wierność Boga względem siebie i wyraz Jego absolutnej suwerenności w miłości. Ze swoim przesłaniem o miłosierdziu jako wierności Boga względem siebie i wobec przymierza oraz Jego nieograniczonej cierpliwości wobec człowieka Franciszek wpisuje się w tradycję nauczania teologicznego, głównie Akwinaty, w spuściznę pozostawioną przez wielu świętych (przykładowo św. Katarzynę Sieneńską, św. Teresę z Lisieux), a także w tradycję nauczania swoich poprzedników (Jana XXIII, Jana Pawła II, Benedykta XVI). Swoim przesłaniem o miłosierdziu papież z Argentyny ujmuje wielu ludzi, zarówno w Kościele, jak i poza nim. Według niektórych teologów pomimo wyraźnego zakorzenienia miłosierdzia w Piśmie Świętym i tradycji Kościoła nauczanie papieża związane z tym zagadnieniem budzi podejrzenia. $\mathrm{W}$ treściach przedstawianych przez Franciszka widzi się powierzchowność i niebezpieczeństwo „słabego duszpasterstwa”, które nie liczy się z innymi zasadami nauki katolickiej, oraz wpływ chrześcijaństwa light czy środka rozmywającego dogmaty i przykazania Boże bądź podważającego znaczenie prawdy. Podkreślanie miłosierdzia, co widać w słowach papieża, można określić nową zasadą hermeneutyczną, która charakteryzuje się przejściem od metody dedukcyjnej do indukcyjnej w sensie „widzieć-oceniać-działać”. Punktem wyjścia w postępowaniu indukcyjnym jest złożona rzeczywistość, a dopiero w kolejnym kroku stosuje się kryteria teologiczne. Nie chodzi przy tym w żaden sposób o zmianę czy odrzucenie dotychczas obowiązujących treści, lecz o perspektywę i horyzont, w których są one postrzegane i rozumiane. Przepowiadanie miłosierdzia przez Franciszka nie zatrzymuje się na etapie pięknej nowomowy ani pustych słów, ale stanowi konkretną opcję na rzecz ubogich i domaga się wcielenia w rozumienie i działalność Kościoła, będącego sakramentem Bożego miłosierdzia ${ }^{26}$.

Przekonanie, że miłosierdzie powinno być w centrum teologii Franciszek wyraził w adhortacji apostolskiej Evangelii gaudium. Wspominając o porządku czy hierarchii prawd nauki katolickiej, zwrócił uwagę, że pochodzą one z tego samego boskiego źródła i należy w nie wierzyć tą samą wiarą, ale niektóre z nich są ważniejsze, bo bardziej bezpośrednio wyrażają orędzie Ewangelii, czyli piękno zbawczej miłości Boga objawionej w Jezusie Chrystusie. Hierarchia prawd łączy się z ich zróżnicowanym związkiem z podstawami wiary chrześcijańskiej i dotyczy zarówno dogmatów, jak i całości nauczania Kościoła, w tym w zakresie moralności. Powołując się na św. Tomasza z Akwinu, Franciszek przypomniał, że miłosierdzie jest największą cnotą. Istnieje wprawdzie spójność między prawdami

26 W. Kasper, Papst Franziskus - Revolution der Zärtlichkeit und der Liebe, s. 45-52. Więcej na temat miłosierdzia w nauczaniu Franciszka, zob.: M.M. Lintner, ,,Miserando atque eligendo” - Zur Spiritualität der Barmherzigkeit bei Papst Franziskus, „Brixner Theologisches Jahrbuch/Annuario Teologico Bressanone” (2015), s. 71--87; E. Borgman, Ein Feldlazarett nach einer Schlacht. Barmherzigkeit als grundlegendes Merkmal von Gottes Gegenwart, Concilium (D) 53 (2017), z. 4, s. $424-433$. 
wiary i cnotami, która nie pozwala wykluczać żadnej z nich z ideału chrześcijańskiego, ale poszczególne prawdy i cnoty muszą być powiązane z całością orędzia chrześcijańskiego, a niektóre z nich mają centralne znaczenie. Ewangelia stanowi zaproszenie, by odpowiedzieć Bogu, który kocha i zbawia człowieka, rozpoznając Go w innych i wychodząc poza siebie w celu poszukiwania dobra wszystkich. Na służbie temu zadaniu pozostają wszelkie cnoty. Poważne niebezpieczeństwo pociąga za sobą głoszenie akcentów doktrynalnych lub moralnych wywodzących się z określonych opcji ideologicznych, a nie z samej Ewangeliii ${ }^{27}$.

Miłosierdzie w nauczaniu Franciszka jest imieniem Boga, Jego postawą obdarowania samym sobą i gotowości do przebaczenia. Doświadczenie Bożego miłosierdzia, wynikającego z troski Boga o każdego człowieka, prowadzi do pełnienia uczynków miłosierdzia, w których wyraża się współczucie wobec bliźniego i udział w jego cierpieniu. W ten sposób miłosierdzie, bezwarunkowo doświadczane przez daną osobę, staje się jej misją, zwłaszcza wobec ludzi biednych, chorych, ubogich, głodnych, spragnionych, migrantów, jak tradycyjnie zostało to sformułowane w uczynkach miłosierdzia wobec ciała. Są one wezwaniem do wyznania wiary w Boga, który przezwycięża odrzucenie i marginalizację przez współczucie i miłosierdzie ${ }^{28}$.

Franciszek w swoim nauczaniu o miłosierdziu wyraźnie nawiązuje do myśli św. Tomasza z Akwinu, według której uczynki miłosierdzia są odpowiedzią na ukrytą Bożą obecność, a także wyrazem tęsknoty, aby daną osobę obdarzyć tym, czego jej brakuje. Chodzi zarówno o świadomość, że bliźni odczuwa brak czegoś, co byłoby dla niego dobre, jak i o właściwe zrozumienie jego wewnętrznej wartości i godności. Nie mówimy zatem o współczuciu w negatywnym sensie tego słowa. Miłosierdzie oznacza uznanie innych jako Bożego stworzenia i wyrazu Jego dobroci. Bóg powołał do istnienia stworzenia, aby objawiła się w nich Jego dobroć i przez nie była reprezentowana. $Z$ tej racji, że jedno stworzenie w wystarczający sposób nie ukaże dobroci Najwyższego, stworzył On inne istoty, aby przez nie urzeczywistnić to, czego brakuje pozostałym. Każde stworzenie, przede wszystkim każda istota ludzka, wnosi coś niepowtarzalnego do dobra wspólnego. W tym kontekście miłosierdzie oznacza dostrzeganie braków, jakie doskwierają ludziom, aby mogli rozwinąć swoje możliwości zgodnie z zamysłem Bożym. Miłosierdzie stwarza możliwości tam, gdzie ich nie ma. W ten sposób wszyscy otrzymują szansę stania się tym, kim być powinni - niepowtarzalnymi wyrazami Bożej dobroci, które przyczyniają się do dobra wspólnego. W ten sposób miłosierdzie w przekonaniu papieża prowadzi do lepszego społeczeństwa. Miłosierna kontemplacja oznacza postrzeganie wszystkich ludzi nie jako ciężarów albo konkurentów w walce o ograniczone i niewystarczające pożywienie bądź mieszkanie, ale jako ubogacające

27 EG 36-39.

28 D.M. Rwezaura, Die Logik bedingungsloser Liebe: Barmherzigkeit aus der Sicht von Flüchtlingen, Concilium (D) 53 (2017), z. 4, s. 454-455. 
i dobroczynne źródło odnowy. Tak rozumiane miłosierdzie, nawiązujące do myśli Akwinaty, jest w nauczaniu Franciszka ostateczną podstawą ,preferencyjnej opcji na rzecz ubogich" 29 .

Uprzywilejowanym kontekstem nauczania papieża na temat miłosierdzia odczytywanego jako otwarcie serca i rąk jest postawa wobec migrantów. Powołując się na objawienie biblijne, Franciszek zwrócił uwagę, że zachęca ono do przyjęcia obcokrajowców. Uzasadnił swoje słowa zapewnieniem, że czyniąc tak, otwiera się drzwi Bogu, a w obliczu drugiej osoby objawiają się rysy twarzy Chrystusa. Migranci są braćmi i siostrami poszukującymi lepszego życia, z dala od ubóstwa, głodu, wyzysku i niesprawiedliwego podziału zasobów ziemi, które powinny należeć równo do wszystkich ludzi. Postawa obojętności wobec migrantów i milczenie, bierne przyglądanie się temu, jak giną przez uduszenie, z głodu, na skutek przemocy i zatonięć, prowadzi do współwiny. Wobec tych problemów Kościół powinien kierować się miłosierdziem, które rodzi solidarność względem bliźniego oraz budzi odpowiedzialność za niego w formie troski o dobre relacje, zdolność przezwyciężania uprzedzeń i lęków oraz budowania kultury spotkania i gościnności. Istotne jest spojrzenie na migrantów nie tylko z punktu widzenia ich statusu, ale przede wszystkim w odniesieniu do nich jako do osób, które mogą przyczynić się do dobrobytu i rozwoju wszystkich. Spotkanie i przyjęcie bliźniego odpowiada przyjęciu samego Boga ${ }^{30}$.

W jednym z przemówień Franciszek, poruszając problem migracji, wyraźnie nawiązał do uczynków miłosierdzia chrześcijańskiego. Zachęcił do odkrycia w tym społecznym zjawisku ręki Boga, który w swojej mądrości posyła do nas człowieka głodnego, aby go nakarmić; spragnionego, aby go napoić; obcego, aby go przyjąć; nagiego, aby go przyodziać. Dla społeczeństw jest to sprawdzian bycia ludem, który można uznać za swoiste kompendium tego, co w człowieku szczere, głębokie $\mathrm{i}$ istotne. Jako lud społeczeństwa przyjmują obcego niczym swojego brata ${ }^{31}$.

Logika miłosierdzia jest również podstawą podejścia do osób znajdujących się w różnych sytuacjach nieregularnych, w tym ludzi rozwiedzionych, żyjących w powtórnych związkach cywilnych. Zadaniem Kościoła jest głoszenie pełnego ideału Ewangelii i wynikającego stąd nauczania o małżeństwie i rodzinie, ale jednocześnie przyjęcie postawy logiki współczucia dla ludzi słabych i unikania ich

29 E. Borgman, Ein Feldlazarett nach einer Schlacht, s. 428-429.

30 Franciszek, Kiedy milczenie staje się wspótwina. Orędzie na Światowy Dzień Migranta i Uchodźcy 2016 r., „L'Osservatore Romano” (Pl) 36 (2015), nr 10, s. 10-12; K. Glombik, Franciszek - kontrowersyjne nauczanie czy kontrowersyjna recepcja?, w: M. Lis (red.), Mosty, nie mury. 5 lat pontyfikatu Franciszka, Opole: Redakcja Wydawnictw Wydziału Teologicznego UO 2018, s. 133-134.

31 Franciszek, Niech bogata Europa przyjmie głodnych braci. Do uczestników konferencji zorganizowanej przez Fundacje im. Romana Guardiniego (13.11.2015), „L'Osservatore Romano” (Pl) 35 (2015), nr 12, s. 40; Franciszek, , Nieletni migranci, bezbronni i bez głosu”. Orędzie na Światowy Dzień Migranta i Uchodźcy 2017 r., „L'Osservatore Romano” (Pl) 37 (2016), nr 11, s. 5; K. Glombik, Franciszek - kontrowersyjne nauczanie czy kontrowersyjna recepcja?, s. 135. 
prześladowania lub wydawania zbyt surowych i niecierpliwych osądów ${ }^{32}$. W obliczu kwestii złożonych i delikatnych należy dokonywać rozeznania duszpasterskiego, które kieruje się miłością miłosierną i gotowe jest zrozumieć, przebaczyć, czekać, a przede wszystkim włączać. Należy dbać o integralność nauczania moralnego Kościoła oraz uważnie ukazywać i zachęcać do najwznioślejszych i centralnych wartości Ewangelii, szczególnie prymatu miłości jako odpowiedzi na bezinteresowną inicjatywę miłości Boga. Miłosierdziu Bożemu nie należy jednak stawiać warunków, bo wtedy zostaje ogołocone z konkretnego sensu i realnego znaczenia, co jest najpoważniejszym sposobem rozmycia treści ewangelicznych. Miłosierdzie nie wyklucza sprawiedliwości i prawdy, ale stanowi ich pełnię i najjaśniejszą manifestację w odniesieniu do Boga. W konsekwencji nieadekwatną okazuje się koncepcja teologiczna, która kwestionuje wszechmoc Bożą, a w szczególności miłosierdzie ${ }^{33}$.

Miłosierdzie jest podstawą rozstrzygnięcia w kwestii możliwości przystępowania do sakramentów świętych - pokuty i pojednania oraz komunii św. w pojedynczych przypadkach osób żyjących w związkach niesakramentalnych po rozwodzie cywilnym. Rozstrzygnięcie to ani nie zrywa z tradycją nauczania Kościoła, ani nie rozmywa czy też nie podważa prawdy o nierozerwalności małżeństwa, jak twierdzą niektórzy krytycy adhortacji Amoris laetitia. Jest ono zaś zakotwiczone $\mathrm{w}$ tradycji i solidnie uzasadnione teologicznie. Zaprezentowane w adhortacji stanowisko o obiektywnej sytuacji grzechu przy braku subiektywnej winy i w związku z tym możliwości życia w łasce Bożej i wzrastania w życiu łaski oraz miłości, otrzymując w tym pomoc Kościoła (w pewnych przypadkach może to być pomoc sakramentów pokuty i Eucharystii ${ }^{34}$, nie zrywa z tradycją Kościoła, ale odchodzi od zawężonego, neoscholastycznego ujęcia tego problemu, co stanowiło podstawę dotychczasowej praktyki ${ }^{35}$.

Postawa miłosierdzia i integracji, jaką Franciszek postuluje w odniesieniu do złożonej sytuacji życiowej poszczególnych ludzi, wyraża się w indywidualnym podejściu do człowieka i jego konkretnej sytuacji. Zgodnie z tradycją chodzi o ocenę nie samego tylko uczynku, ale o uwzględnienie w niej także poczytalności i winy człowieka, by dzięki temu powierzyć go Bożemu miłosierdziu odpowiednio do ich ciężaru. W ten sposób prymat nad generalizującym osądem zdobywa ocena sytuacji poszczególnych osób. Jest to zgodne z tradycją Kościoła, w której wykluczenie ze wspólnoty eucharystycznej nie miało charakteru absolutnego. Ponadto istniała możliwość dopuszczania do komunii eucharystycznej ludzi żyjących w stanie obiektywnego nieporządku moralnego w przypadku, kiedy pokuta stałaby się dla

32 Franciszek, Adhortacja apostolska ,Amoris laetitia”, Watykan 2016 (dalej: AL), nr 307-308.

33 AL 310-312; E. Borgman, Ein Feldlazarett nach einer Schlacht, s. 425.

34 AL 305, przypis 351.

35 E. Schockenhoff, Traditionsbruch oder notwendige Weiterbildung? Zwei Lesarten des nachsynodalen Schreibens Amoris laetitia, „Stimmen der Zeit” (2017), n. 3, s. 153; W. Kasper, Die Botschaft von Amoris laetitia. Ein freundlicher Disput, Freiburg in Br.: Herder 2018, s. 73-77. 
penitenta ciężarem nie do udźwignięcia, czyli domagałaby się odcięcia od sytuacji, w którą grzesznik jest uwikłany, ale jednocześnie wyrządziłby szkodę osobom, za które ponosi odpowiedzialność. Ponadto mogą występować okoliczności, w których dopuszczenia do komunii nie można uzależnić od zmiany przekonań osób nierozumiejących czy niemogących pojąć stanowiska Kościoła, czyli stan tzw. niepokonalnej ignorancji sumienia pewnego. Inna okoliczność to sytuacja rozterki moralnej, w której stosuje się zasadę wyboru mniejszego zła, jeżeli istnieje alternatywa dwóch złych możliwości. W takim przypadku pierwszeństwo mają konkretne wartości, które można zrealizować w danej sytuacji przed abstrakcyjnymi. Odpowiedzi na pytanie o to, czy zaistniał grzech śmiertelny, oddzielający człowieka od Boga, można udzielić nie tylko na podstawie oceny obiektywnej sytuacji zewnętrznej, ale przy uwzględnieniu subiektywnych aspektów osoby działającej ${ }^{36}$.

W omawianej kwestii Amoris laetitia nawiązuje do zasady dotyczącej okoliczności łagodzących, na podstawie której zostaje zmniejszona odpowiedzialność moralna człowieka i jego subiektywna wina $\mathrm{z}$ racji niewiedzy, braku zrozumienia lub z powodu sytuacji, która nie pozwala mu działać zgodnie z normą moralną. Ważne jest przy tym rozeznanie duszpasterskie, w ramach którego można dojść do przekonania, że konsekwencje i skutki danej normy z racji okoliczności łagodzących nie muszą być w każdym przypadku takie same, a w kwestii dostępu do sakramentów należy brać pod uwagę stopień odpowiedzialności moralnej osób, których ten problem dotyczy. Kwestia osobistej winy jest podstawą twierdzenia, że nie w każdym przypadku nieregularnej sytuacji da się mówić o stanie grzechu i utracie łaski uświęcającej. Rozeznanie duszpasterskie powinno zostać dopełnione osobistym poznaniem osoby, której sprawa dotyczy poprzez ocenę jej możliwości życia w łasce Bożej i wzrostu w miłości w sytuacji obiektywnego grzechu, w której jednak brakuje subiektywnej winy lub jest ona pomniejszona, co stanowi istotny element dowartościowania podmiotu ${ }^{37}$.

Innym aktualnym zagadnieniem, w którym miłosierdzie stało się podstawą nowego spojrzenia na wielowiekowe nauczanie Kościoła, jest problematyka kary śmierci. W przyjętym w sierpniu 2018 r. reskrypcie w sprawie ponownego sformułowania w Katechizmie Kościoła Katolickiego punktu poświęconego karze

36 S. Müller, Die Entflechtung des Gordischen Knotens: Zur Stärkung der Moraltheologie durch Amoris laetitia, „Studia Teologiczno-Historyczne Śląska Opolskiego” 37 (2017), n. 1, s. 92-93; S. Müller, Rozplątywanie węzła gordyjskiego. Wzmocnienie teologii moralnej dzięki Amoris laetitia, „Więź” (2018), nr 2, s. 155-156; B. Petrà, From Familiaris consortio to Amoris laetitia: Continuity of the Pastoral Attitude and a Step Forward, „Intams Review” 22 (2016), no 2, s. 212; E. Schockenhoff, Traditionsbruch oder notwendige Weiterbildung?, s. 153; W. Kasper, Die Botschaft von Amoris laetitia, s. 73-77. Przykłady rozeznawania konkretnych kazusów w oparciu o wskazania Amoris laetitia zob.: A. Muszala, Rozeznanie w Amoris laetitia papieża Franciszka, w: Sz. Drzyżdżyk, M. Gilski (red.), Rozeznanie. Przeszłość, teraźniejszość, przyszłość, Kraków: Scriptum 2019, s. 223-232.

37 T. Knieps-Port le Roi, Licht am Ende des Tunnels. Ein Rückblick auf den synodalen Prozess zur Ehe- und Familienthematik, „ET-Studies” 8 (2017), n. 1, s. 131-133. 
śmierci, znajdziemy konkluzję: „, [...] Kościół w świetle Ewangelii naucza, że «kara śmierci jest niedopuszczalna, ponieważ jest zamachem na nienaruszalność i godność osoby» i z determinacją angażuje się na rzez jej zniesienia na całym świecie" ${ }^{\prime 3}$. Franciszek, umieszczając to zagadnienie w kontekście godności osoby ludzkiej, wpisuje się w tradycję nauczania Kościoła na ten temat, wyrażanego zwłaszcza w okresie pontyfikatów Jana Pawła II i Benedykta XVI. Jednocześnie poprzez swoje jednoznaczne stanowisko, którego wyrazem jest zmiana tekstu Katechizmu Kościoła Katolickiego, potwierdza, że nauczanie Kościoła o karze śmierci ewoluuje, pozostając spójne z wcześniejszym nauczaniem. Jest to przykład postępu dogmatycznego w zakresie treści wiary, która stopniowo dojrzewała do zrozumienia, że stosowania kary śmierci nie da się pogodzić z wiarą chrześcijańską. Chodzi o rozwój i postęp w rozumieniu Ewangelii, co otwiera dotąd ukryte perspektywy i stanowi kolejny krok w zakresie interpretacji niezmiennego nauczania. Papież nie ma na myśli pobłażania bezprawiu, ale wymóg, by wymiar sprawiedliwości nie kierował się urazą i chęcią zemsty, oraz przekonanie, że każdy rodzaj pozbawienia człowieka życia pozostaje sprzeczny z objawieniem chrześcijańskim, a nawrócenie, skrucha i pragnienie rozpoczęcia nowego etapu życia nie mogą nikomu zostać odebrane, także ludziom, którzy dopuścili się najcięższych zbrodni ${ }^{39}$.

W jednym z przemówień na temat kary śmierci, wśród wielu racji przeciwko temu wymiarowi kary, Franciszek przywołał argument teologiczny związany z miłosierdziem. Papież stwierdził, że najwyższy wymiar kary obraża nienaruszalność życia i godność osoby ludzkiej. Jest też sprzeczny z zamysłem Boga wobec człowieka i społeczeństwa oraz Jego miłosierną sprawiedliwością. Najwyższy wymiar kary nie oddaje sprawiedliwości ofiarom, ale inspiruje do zemsty i dowodzi porażki państwa, gdyż zmusza do zabijania w imię sprawiedliwości. Kara śmierci jest niezgodna z humanitas oraz Bożym miłosierdziem, które powinny stanowić wzorzec ludzkiej sprawiedliwości, będącej niedoskonałą, a uznawanie jej nieomylności może w konsekwencji uczynić ją źródłem niesprawiedliwości. Stosowanie kary śmierci pozbawia skazanego możliwości wynagrodzenia lub naprawy wyrządzonej szkody, wyznania win, przez które człowiek wyraża swoje nawrócenie, oraz okazania skruchy, będącej wstępem do żalu za grzechy i pokuty, co z kolei umożliwia spotkanie z miłosierną i uzdrawiającą miłością Boga. Ponadto kara śmierci przeczy miłości nieprzyjaciół, którą głosi Ewangelia. Zaangażowanie na rzecz zniesienia

38 Rescriptum ex audientia sanctissimi. Nowe sformułowanie n. 2267 Katechizmu Kościoła Katolickiego, „L'Osservatore Romano” (Pl) 39 (2018), nr 8-9, s. 53; problematyka kary śmierci i kar kryminalnych stała się także tematem innego przemówienia papieża Franciszka: Franciszek, Dożywocie to ukryta kara śmierci. Przemówienie do delegacji Międzynarodowego Stowarzyszenia Prawa Karnego, „L'Osservatore Romano” (Pl) 35 (2014), nr 11, s. 37-41.

39 R. Fisichella, Kara śmierci jest niedopuszczalna, „L'Osservatore Romano” (Pl) 39 (2018), nr 8-9, s. 54; M. Seewald, Todesstrafe, Kirchenlehre und Dogmenentwicklung. Überlegungen zur von Papst Franziskus vorgenommenen Änderung des Katechismus, Concilium (D) 55 (2019), z. 1, s. $106-110$. 
tej formy kary świadczy o miłosierdziu i czułości Boga ${ }^{40}$. O ile sprzeciw wobec kary śmierci wpisuje się w długą tradycję rozwijającego się stanowiska Kościoła na ten temat, które ewoluowało od dystansu wobec najwyższego wymiaru kary aż do postulatów jej zniesienia, to argumentacja nawiązująca do teologii miłosierdzia jest nowością, którą w tę złożoną problematykę wnosi nauczanie papieża Franciszka. W jego przekonaniu wymierzanie najwyższego wymiaru kary pozostaje sprzeczne z centralnym przesłaniem Ewangelii, czyli Bożym miłosierdziem, które nie unicestwia, ale prowadzi do nawrócenia.

Niektóre rozstrzygnięcia i aspekty nauczania Franciszka mogą rodzić wątpliwości i prowadzić do niezrozumienia i sporów teologicznych o ich interpretacje. Od samego początku pontyfikat papieża z Argentyny odróżnia się od tych dotychczas znanych nie tylko specyficznymi gestami i zachowaniami, ale także stanowiskami i treściami dotykającymi samych podstaw wiary. Ich właściwe zrozumienie nie jest możliwe bez odniesienia do odmiennego kontekstu kulturowego, z którego wywodzi się papież, i związanych z nim specyficznych problemów i treści inspirujących jego nauczanie. Niniejszy tekst ukazuje trzy elementy specyfiki teologii w nauczaniu Franciszka, którymi są: teologia ludu, duchowość ignacjańska oraz tomistyczne ujęcie biblijnego pojęcia miłosierdzia. Bez refleksji nad inspiracją myśli teologicznej zrozumienie szczegółowych wątków w nauczaniu i przewodzeniu Kościołowi przez papieża z Argentyny okazuje się niemożliwe i może prowadzić do błędnych wniosków. Podsumowując, należy stwierdzić, że nauczanie Franciszka jest zakorzenione w Piśmie Świętym, w wielowiekowej tradycji teologicznej i nauczaniu Soboru Watykańskiego II. Stanowi ono ich kontynuację. ale wykazuje także pewne nowe aspekty, które uwydatniają znaczenie głosu dotychczas słabo słyszanego w przestrzeni Kościoła powszechnego.

40 Franciszek, Porażka dla państwa prawa. List do przewodniczacego Międzynarodowej Komisji Przeciwko Karze Śmierci, „L'Osservatore Romano” (Pl) 36 (2015), nr 3-4, s. 33. Argumentacja związana z zadośćuczynieniem, wyznaniem i nawróceniem jest obecna także w innym wystąpieniu papieża Franciszka na temat problematyki prawa karnego: Francesco, Lettera ai pertecipanti al XIX Congresso Internationale dell'Associazione Internationale di diritto penale e del III Congresso dell'Associazione Latinoamericana di diritto Penale e Criminologia, http://w2.vatican.va/content/ francesco/it/letters/2014/documents/papa-francesco_20140530_lettera-diritto-penale-criminologia. html [dostęp: 9 V 2019]. 


\section{SPECYFICZNE ASPEKTY TEOLOGII W NAUCZANIU PAPIEŻA FRANCISZKA}

\section{Streszczenie}

Specyfika pontyfikatu Franciszka nie polega jedynie na spektakularnych gestach i nowym języku, ale przejawia się również w głoszonych przez niego treściach. Artykuł ten jest próbą ogólnego przedstawienia głównego przesłania nauczania papieża z Argentyny i jego zasadniczych inspiracji teologicznych, które wyjaśniają optykę i specyficzne akcenty teologiczne jego pontyfikatu. Punkt wyjścia stanowi prezentacja teologii ludu, która znajduje się w centrum myśli i nauczania Franciszka o Kościele i tworzy podstawę do rozumienia wszelkich innych zagadnień, także społecznych. W dalszej kolejności jest mowa o elementach duchowości ingacjańskiej, mającej wpływ na sposób ujęcia zagadnień teologicznych w nauczaniu jezuickiego papieża. Na końcu przedmiotem refleksji jest miłosierdzie będące kluczowym pojęciem teologicznym w koncepcji Franciszka, które znajduje aplikację w rozumieniu zagadnień szczegółowych. Analiza nauczania papieskiego prowadzi do wniosku, że jest ono zakorzenione w Piśmie Świętym, wielowiekowej tradycji teologicznej i nauczaniu Soboru Watykańskiego II, stanowiąc ich kontynuację, ale wykazuje także nowe aspekty, które eksponują głos dotychczas słabo słyszany w Kościele powszechnym.

Słow a kluczowe: Franciszek, teologia ludu, duchowość ignacjańska, miłosierdzie, Evangelii gaudium, Amoris laetitia.

\section{SPECIFIC ASPECTS OF THEOLOGY IN THE TEACHING OF POPE FRANCIS}

\section{Summary}

The pontificate of Pope Francis has a specific character that does not consist only in spectacular gestures or a new language but is also manifested in the contents of his teaching. The presented paper is an attempt to outline the main message in the teaching of Pope Francis and his most important theological inspirations which explain the point of view and specific theological features of his pontificate. The theology of the people is the starting point of the paper as it is central to Francis' thought about the Church and constitutes the basis for his understanding of social questions. Then, elements of Ignatian spirituality will be presented as they have impact on the manner of presenting theological themes by the Jesuit Pope. The last point introduces a reflection about mercy, which is the key theological idea in the teaching of Francis and finds application in the understanding of many specific questions. The analysis of Francis' teaching confirms that it is based on the Bible, the theological tradition of the Church and the teaching of the Second Vatican Council, and shows specific new aspects which have been treated as hardly audible voices in the world Church so far.

K e y w ord s: Francis, theology of the people, Ignatian spirituality, mercy, Evangelii gaudium, Amoris laetitia. 


\section{SPEZIFISCHE ASPEKTE DER THEOLOGIE IN DER LEHRE VON PAPST FRANZISKUS}

\section{Zusammenfassung}

Die Besonderheit des Pontifikats von Papst Franziskus liegt nicht nur in den spektakulären Gesten und der neuen Sprache, sondern sie manifestiert sich auch in den Inhalten, die verkündet werden. Der vorliegende Text ist ein Versuch, die Hauptbotschaft der Lehre von Papst Franziskus und seine wesentlichen theologischen Inspirationen zu umreißen, welche die Optik und die spezifischen theologischen Akzente seines Pontifikats erklären. Der Ausgangspunkt ist die Darstellung der Theologie des Volkes, die im Zentrum der Gedanken und der Lehre von Papst Franziskus über die Kirche steht und die Grundlage für das Verständnis aller anderen, auch sozialen Fragen bildet. Des Weiterem gibt es Elemente der ignatianischen Spiritualität, welche die Art und Weise beeinflussen, in der die theologischen Fragen in der Lehre des Jesuitenpapstes dargestellt werden. Schließlich bildet die Barmherzigkeit das Thema der Reflexion, ein theologisches Schlüsselkonzept in der Lehre von Papst Franziskus, das beim Verständnis spezifischer Fragen seine Anwendung findet. Eine Analyse der Lehre von Papst Franziskus führt zu der Schlussfolgerung, dass sie in der Heiligen Schrift, in einer jahrhundertealten theologischen Tradition und in den Lehren des Zweiten Vatikanischen Konzils verwurzelt ist und dass sie eine Fortsetzung dieser Lehren darstellt, aber auch neue Aspekte offenbart, die den Nachhall einer bisher in der Universalkirche kaum gehörten Stimme darstellen.

S c h lü s s e lw ö r te r : Franziskus, Theologie des Volkes, ignatianische Spiritualität, Barmherzigkeit, Evangelii gaudium, Amoris laetitia.

\section{BIBLIOGRAFIA}

Barth G., Amoris laetitia - ciagłość czy zerwanie? Kwestie hermeneutyczne, w: J. Goleń (red.), Towarzyszyć matżeństwu i rodzinie. Inspiracje adhortacji apostolskiej Amoris laetitia dla duszpasterstwa rodzin, Lublin: TN KUL 2017, s. 25-50.

Borghesi M., Jorge Mario Bergoglio. Biografia intelektualna. Dialektyka i mistyka, tłum. D. Chodyniecki, Kraków: Bratni Zew 2018.

Borgman E., Ein Feldlazarett nach einer Schlacht. Barmherzigkeit als grundlegendes Merkmal von Gottes Gegenwart, ConcD 53 (2017), z. 4, s. 424-433.

Comeau G., La dynamique spirituelle de L'Église dans le monde, selon le pape François. Point de vue d'une théologienne françasie, „ET-Studies” 9 (2018), n. 1, s. 51-60.

Fisichella R., Kara śmierci jest niedopuszczalna, „L'Osservatore Romano” (Pl) 39 (2018), nr 8-9, s. 54.

Francesco, Lettera ai pertecipanti al XIX Congresso Internationale dell'Associazione Internationale di diritto penale e del III Congresso dell'Associazione Latinoamericana di diritto Penale e Criminologia, http://w2.vatican.va/content/francesco/it/letters/2014/documents/ papa-francesco_20140530_lettera-diritto-penale-criminologia.html [dostęp: 9 V 2019]. 
Franciszek, Adhortacja apostolska „Amoris laetitia”, Watykan 2016.

Franciszek, Adhortacja apostolska „Evangelii gaudium”, Watykan 2013.

Franciszek, Dożywocie to ukryta kara śmierci. Przemówienie do delegacji Międzynarodowego Stowarzyszenia Prawa Karnego, „L'Osservatore Romano” (Pl) 35 (2014), nr 11, s. 37-41.

Franciszek, Kiedy milczenie staje się wspótwiną. Orędzie na Światowy Dzień Migranta i Uchodźcy 2016 r., „L'Osservatore Romano” (Pl) 36 (2015), nr 10, s. 10-12.

Franciszek, Niech bogata Europa przyjmie głodnych braci. Do uczestników konferencji zorganizowanej przez Fundację im. Romana Guardiniego (13.11.2015), „L'Osservatore Romano" (Pl) 35 (2015), nr 12, s. 40.

Franciszek, Niech Duch Święty da nam łaskę nawrócenia i zadośćuczynienia. List do Ludu Bożego, „L'Osservatore Romano” (Pl) 39 (2018), nr 8-9, s. 7-9.

Franciszek, „,Nieletni migranci, bezbronni i bez głosu”. Orędzie na Światowy Dzień Migranta i Uchodźcy 2017 r., „L'Osservatore Romano”(Pl) 37 (2016), nr 11, s. 5.

Franciszek, Piękno chrześcijańskiej rodziny. Przemówienie do członków Papieskiego Instytutu Studiów nad Matżeństwem i Rodzina im. Jana Pawła II (27.X.2016), „L’Osservatore Romano" (Pl) 37 (2016), nr 11, s. 33-35.

Franciszek, Porażka dla państwa prawa. List do przewodniczacego Międzynarodowej Komisji Przeciwko Karze Śmierci, „L’Osservatore Romano” (P1) 36 (2015), nr 3-4, s. 32-33.

Franciszek, Rachunek sumienia. Przemówienie do członków Kurii Rzymskiej (22 XII 2014), „L'Osservatore Romano” (Pl) 36 (2015), nr 1, s. 39-42.

Franciszek, Wolton D., Otwieranie drzwi. Rozmowy o Kościele i świecie, thum. M. Chojnacki, Kraków: WAM 2017.

Galli C.M., Ein Lateinamerikaner in Rom. Franziskus und die argentinische Theologie des Gottesvolkes, „Herder Korrespondenz Spezial” (2015), n. 1, s. 16-19.

Gillen E., Leadership in eine offene Zukunft! Die Papst-Franziskus Formel, „Studia Teologiczno-Historyczne Śląska Opolskiego"36 (2016), n. 2, s. 11-30.

Gillen E., Menschliche Sicherheit ethisch aufladen und politisch nutzbar machen, „Concilium" (D) 54 (2018), z. 2, s. 136-143.

Glombik K., Franciszek - kontrowersyjne nauczanie czy kontrowersyjna recepcja?, w: M. Lis (red.), Mosty, nie mury. 5 lat pontyfikatu Franciszka, Opole: Redakcja Wydawnictw Wydziału Teologicznego UO 2018, s. 131-149.

Gomes Moreira J.A., Fünf Jahre Franziskus - aus der Perspektive der Befreiungstheologie, „ET-Studies”9 (2018), n. 1, s. 61-88.

Kasper W., Die Botschaft von Amoris laetitia. Ein freundlicher Disput, Freiburg in Br.: Herder 2018.

Kasper W., Papst Franziskus - Revolution der Zärtlichkeit und der Liebe. Theologische Wurzeln und pastorale Perspektiven, Stuttgart: Katholisches Bibelwerk 2015.

Knieps-Port le Roi T., Licht am Ende des Tunnels. Ein Rückblick auf den synodalen Prozess zur Ehe- und Familienthematik, „ET-Studies” 8 (2017), n. 1, s. 119-137.

Lintner M.M., „,Miserando atque eligendo” - Zur Spiritualität der Barmherzigkeit bei Papst Franziskus, „Brixner Theologisches Jahrbuch/Annuario Teologico Bressanone” (2015), s. 71-87.

Luciani R., Der zentrale Stellenwert des Volkes in der Soziokulturellen Theologie von Papst Franziskus, „Concilium” (D) 54 (2018), z. 3, s. 297-308. 
Müller S., Die Entflechtung des Gordischen Knotens: Zur Stärkung der Moraltheologie durch Amoris laetitia, „Studia Teologiczno-Historyczne Śląska Opolskiego”37 (2017), n. 1, s. 79-103.

Müller S., Rozplątywanie węzła gordyjskiego. Wzmocnienie teologii moralnej dzięki Amoris laetitia, „Więź” (2018), nr 2, s. 148-160.

Muszala A., Rozeznanie w Amoris laetitia papieża Franciszka, w: Sz. Drzyżdżyk, M. Gilski (red.), Rozeznanie. Przeszłość, teraźniejszość, przyszłość, Kraków: Scriptum 2019, s. 221-251.

Noceti S., Volk Gottes: Eine noch nicht vollendete Wiederfindung des Selbstverständnisses der Kirche, „Concilium” (D) 54 (2018), z. 3, s. 240-252.

Petrà B., From Familiaris consortio to Amoris laetitia: Continuity of the Pastoral Attitude and a Step Forward, „Intams Review” 22 (2016), no 2, s. 202-216.

Pottmeyer H.J., Volk Gottes auf dem Weg. Das Kirchenverständnis von Papst Franzskus als Schlüssel zu Amoris laetitia, w: S. Goertz, C. Wittig (ed.), Amoris laetitia - Wendepunkt für die Moraltheologie?, Freiburg im Br.: Herder 2016, s. 326-328.

Renner P., L'ecclesiologia fondata nella Biografia di Papa Francesco, „Brixner Theologisches Jahrbuch/Annuario Teologico Bressanone" (2015), s. 151-168.

Rescriptum ex audientia sanctissimi. Nowe sformułowanie n. 2267 Katechizmu Kościoła Katolickiego, „L'Osservatore Romano” (Pl) 39 (2018), nr 8-9, s. 53.

Rwezaura D.M., Die Logik bedingungsloser Liebe: Barmherzigkeit aus der Sicht von Flüchtlingen, „Concilium” (D) 53 (2017), z. 4, s. 453-461.

Scannone J.C., Pope Francis and the Theology of the People, „Theological Studies” (2016), no 1, s. $118-135$.

Schärtl T., Amerikanischer Albtraum. Die perfide Interpretation des Missbrauchs, „Stimmen der Zeit" (2018), n. 11, s. 753-767.

Schockenhoff E., Traditionsbruch oder notwendige Weiterbildung? Zwei Lesarten des nachsynodalen Schreibens Amoris laetitia, „Stimmen der Zeit” (2017), n. 3, s. 147-158.

Seewald M., Todesstrafe, Kirchenlehre und Dogmenentwicklung. Überlegungen zur von Papst Franziskus vorgenommenen Änderung des Katechismus, „Concilium” (D) 55 (2019), z. 1, s. $100-112$.

Strube S.A., Widerstand gegen Papst Franziskus und seine Reformen. Empirische Beobachtungen am Beispiel der Internetseite kath.net, „ET-Studies” 9 (2018), n. 1, s. 27-50.

Tomasi M., Quattro principi per dare forma ad un popolo. Il contributo dell'esortazione apostolica Evangelii gaudium alla dottrina sociale Della Chiesa, „Brixner Theologisches Jahrbuch/Annuario Teologico Bressanone" (2015), s. 169-185.

Wandinger N., Aus persönlicher Gotteserfahrung unterscheiden, entscheiden und (dramatische) Prozesse anstossen. Zur ignatianischen Spiritualität von Papst Franziskus, „Brixner Theologisches Jahrbuch/Annuario Teologico Bressanone” (2015), s. 201-215.

Weisner Ch., Wendezeit für die römische Kirche. Der schwierige Weg von der Klerikalkirche zu einer Kirche des Gottesvolkes, „ET-Studies” 9 (2018), n. 1, s. 3-26. 
Konrad Józef Glombik - duchowny Kościoła rzymskokatolickiego (diecezja opolska), doktor habilitowany teologii, profesor Uniwersytetu Opolskiego w katedrze Teologii Moralnej, Bioetyki i Prawa Kanonicznego Wydziału Teologicznego, dyrektor Redakcji Wydawnictw Wydziału Teologicznego UO, redaktor naczelny półrocznika „Studia Teologiczno-Historyczne Śląska Opolskiego". Obszary badawcze: katolicka etyka seksualna, personalistyczne koncepcje małżeństwa, sakramentalność małżeństwa. Opublikował m.in.: „Zweieinigkeit” - Herbert Doms (1890-1977) und sein Beitrag zum personalistischen Eheverständnis (Munster: LIT Verlag 2016), Theological ethics in a changing world: contemporary challenges: reorientation of values, change of moral norm? (red., Opole: Wydawnictwo UO 2015), Kościót w Internecie - Internet w Kościele: społeczeństwo internautów a kultura globalna (red. wraz z M. Kalczyńska, Opole: Wydawnictwo UO 2015), Splendors and Shadows of the Ecclesial Character of Moral Theology by Polish Moral Theologians, w: A. Autiero, L. Magesa (red.), The Catholic Ethicist in the Local Church, Catholic Theological Ethics in the World Church, NY: Orbis Books 2018, s. 173-184. Adres do korespondencji: kglombik@uni.opole.pl. 